\title{
Antibacterial properties studies of trunk barks of terminalia ivorensis (Combretaceae), a commercial and medicinal specie, on some methicillin-resistant Staphylococci spp strains.
}

\author{
*coulibaly k. ${ }^{1 ; 3}$;irihi g. N. ${ }^{1}$; guessennd-kouadio n. ${ }^{2}$; ${ }^{3}$; oussou k. R. ${ }^{4}$; dosso m. ${ }^{2}$
}

1. Laboratory of Botany, Unity of Formation and Research Biosciences; University Félix Houphouët Boigny of CocodyAbidjan (Côte d'Ivoire); 22 BP 582 Abidjan 22.

2. Laboratory of Bacteriology-Virology Institute Pasteur of Côte d'Ivoire, 01 BP 490 Abidjan 01.

3. Unity of natural Substances Antibiotics and of Invigilation of the Resistance of Micro-organisms to anti-infectious, Institute Pasteur of Côte d'Ivoire, 01 BP 490 Abidjan 01.

4. Laboratory of chemistry Organic Structural, Unity of Formation and Research of Sciences of the Structure of the material and of the Technology (S.S.M.T.) University Félix Houphouët Boigny of Cocody-Abidjan (Côte d'Ivoire); 22 BP 582 Abidjan 22.

\begin{abstract}
:
Background: Methicillin-resistant Staphylococcus aureus, Staphylococcus epidermidis and coagulase-negative Staphylococcus infections are a worldwide concern. Terminalia ivorensis, of Combretaceae family plant, is widely used traditional medicinal in Côte d'Ivoire to treat dermal diseases (affection in which Staphylococci are implied) including local inflammation and also to treat voice-loss.

Objectives: This study focused to investigate the effect in vitro of the extracts of trunk barks of Terminalia ivorensis on some methicillin/oxacillin-resistant strains of Staphylococcus aureus, S. epidermidis, coagulase-negative S. and reference strain of S. aureus ATCC 25923.

Methods: Antibacterial activity of aqueous, $70 \%$ ethanolic $70 \%$ and aqueous residue extracts was assessed using agar disc-diffusion method and liquid medium microdilution method in 96 multi-well micro-titer plates. This method led us to determine minimum inhibition concentration (M.I.C.) and minimum bactericidal concentration (M.B.C.). The presence of chemical groups major was detected qualitatively.

Results: Aqueous and 70\% ethanolic 70\% extracts showed significant activity against all the bacteria except aqueous residue when compared with the standard antibiotic oxacillin $(5 \mu \mathrm{g} / \mathrm{ml})$. M.I.C. for aqueous and $70 \%$ ethanolic $70 \%$ extracts ranged from $0,83-16,67 \mathrm{mg} / \mathrm{ml}$ and $0,156-13,33 \mathrm{mg} / \mathrm{ml}$ respectively. Viable cell determination revealed the bactericidal nature of the two barks extracts. The 70\% ethanolic 70\% extract exhibited the highest activity according to the M.B.C. values. The phytochemical analysis indicates the presence of tannins, saponins, flavonoids, terpen/sterols, coumarins, polyphenols and traces of alkaloid.

Conclusion: The in-vitro antibacterial efficacy shown by the barks of this plant and his lushness in chimical compounds, would justify use of this one in the traditional treatment of some diseases of microbial origin. These compounds could be suggested to provide alternative solution to the development of new therapeutic agents.
\end{abstract}

Keys words: Terminalia ivorensis, Dermal diseases, Methicillin-resistant, Côte d'Ivoire.

DOI:http://dx.doi.org/10.4314/ahs.v14i3.35

\section{Introduction}

The treatment of the bacterial infections is in general based on the use of antibiotics. Very great often unsuited use of these molecules antibacterial drove the
Corresponding Author:
Coulibaly K,
Laboratory of Botany, Department of
Biosciences, University Félix
Houphouët Boigny of Cocody-Abidjan
(Côte d'Ivoire); 22 BP 582 Abidjan 22.
E-mail: kiyinlma@yahoo.fr
Tel: (00225) 07-99-72-28

selection of strains multi-resistant bacteria. It is the case for example producing bacteria of penicillinase, resistant to all them penicillin such as the penicillin of group A, G and M. Methicillin/oxacillin-resistant staphylococci infections mainly caused by Staphylococcus aureus and by coagulase-negative staphylococci, as S. epidermidis are considered one of the major man pathogenic, causing infections of the skin and fabrics soft.

In Côte d'Ivoire like in the either developing countries, infectious caused by methicillin/oxacillin-resistant Staphylococcus spp. continues to be a growing public health concern. Numerous cases of multi-resistant 
bacteria were reported1; 2; 3. The Staphylococci are involved in various sicknesses and often responsible for infections most frequently contracted in hospitals in nosocomial infections cases4; starting by simple whitlow to the most serious infections like septicaemias, endocarditis, major pneumonias, cellulites and abscesses5; 6. These bacteria give an important number of toxins and extracellular enzymes, and fights against the action of the methicillin/oxacillin and its by-products. So, the effectiveness of antibiotics, considered as the quasiuniversal solution to infections, decreases. Face to the weaknesses of chemotherapy, it is more necessary than and the necessity to find other alternative means in the fight against this resistance. it It is thus significant to direct research towards new ways and especially towards the plants which always have been used as a basis for new drugs.

Terminalia ivorensis A. Chev. (Combretaceae) is a woody species belonging to the category $\mathrm{I}$ of the commercial sawlog of Côte d'Ivoire. The trunk barks presents a rhytidom peeling of the tree in sheets (fig. 1). Its common name is Framiré. In Côte d'Ivoire, the root of this plant is used against voice-loss, and as antipyretic 7 ; 8. The trunk barks are We also used the trunk barks as against woundwort9 and against some cutaneous affection.

Our study consisteds of the research of the antimicrobial activity biological activity of the aqueous, $70 \%$ ethanolic and aqueous residue extracts of the trunk barks of Terminalia ivorensis A. Chev. (Combretaceae) against opposite some bacterial methicillin/oxacillinresistant bacteria strains of Staphylococcus spp., which implied in some dermal diseases, in other to verify its claimed ethno-medicinal use in the treatment of skin infections. To do with, the different extracts underwent a screening phytochemical.

\section{Materials and methods: Vegetable materials}

The trunk barks part of T. ivorensis was collected in Tiassalé, Côte d'Tvoire, in December 2008, and identified by Pr Aké-Assi of the Laboratory of Vegetable Biology University Félix Houphouët Boigny of Cocody-Abidjan. A voucher specimen (voucher $\left.\mathrm{n}^{\circ} 8855\right)$ is deposited in the Herbarium of National Floristic Center of Abidjan.

\section{Bacterial strains}

Microorganisms were obtained from the Laboratory of Bacteriology-Virology of the Institute Pasteur of Côte d'Ivoire. They consist of:
- 01 strain reference of Staphylococcus aureus ATCC 25923

- 14 strains of S. aureus resistant to oxacillin, cefoxitine, rifampicin, ciprofloxacin, tetracycline, gentamycin and some to vancomycin.

- 01 strain of S. epidermidis resistant to cefoxitine, cotrimoxazol, erythromycin, ciprofloxacin, oxacillin and gentamycin.

- 04 strains of coagulase-negative Staphylococcus resistant to fusidic acid, cefoxitin, erythromycin, fosfomycine, cotrimoxazol and oxacillin.

Preparation of extracts

1. Aqueous extract23 and N'guessan9. affections in which the staphylococci are implied.

The phytochemical screening of the extract of the trunk barks of T. ivorensis has shown the presence of saponins, terpens, tannins, polyphenols. These classes of secondary metabolites are known to possess antibacterial activities24. This would explain the bactericidal action of the trunk barks of $\mathrm{T}$. ivorensis. However, negative results observed with aqueous residue, do not mean absence of bioactive constituents nor is that theextract inactive. Active compounds may be present but in insufficient quantities in this crude extract to show activity with the dose levels employed 25 or it could be that its activity is masked by the presence of sugars 26 . We could deduce from that the antibacterial substances contained in the trunk barks of $\mathrm{T}$. ivorensis are more soluble in the $70 \%$ ethanol at $70 \%$ than in water used. The ethanol would then concentrate better the active ingredient27. The presence of those active principles would then justify the use of that plant in the treatment of the skin troubles and local inflammation in the Ivorian traditional pharmacopeia.

\section{Conclusion:}

The lushness of the extracts in chimical compounds, would justify their therapeutic effects and overcoat the use of this plant in the traditional treatment of some diseases of microbial origin. Isolation and purification of different compounds could be suggested to provide alternative solution to the development of new therapeutic agents. This study showed us that the aqueous and ethanolic 70\% extracts were bactericidal on the whole bacterial strains at the origin of some infections in the human and suggest, these extract can provide alternative solution for the treatment of dermal diseases particularly in Côte d'Ivoire where this pathology is always a public health problem. 


\section{Thanks}

We wish to express our gratitude to the Analytic Chemistry Laboratory ofPharmaceutical Sciences of the University Félix Houphouët Boigny of Cocody and the Institute Pasteur of Côte d'Ivoire for their technical help.

\section{Rerences:}

1. Akoua Koffi C. Guessennd N. Gbonon V. FayeKette A. Y. H. Dosso M. Methicillin- resistant of staphylococcus aureus in Abidjan (1998-2001): A new hospital problem. Medicines et maladies infectieuses, 2004; 34 (3) pp. 132-136.

2. Guessennd N. Kacou-N'douba A. Gbonon V. Yapi D. Ekaza E. Dosso M. Courvalin P. Prévalence et profil de résistance des entérobactéries productrices de betalactamases spectre élargi (BLSE) à Abidjan Côte d'Ivoire de 2005 à 2006. Journal des Sciences. Pharmaceutiques et Biologiques, 2008; Vol.9, n¹, pp. 63-70.

3. Akinyemi K. O., Oladapo O., Okwara C. E., Ibe C. C., Fasure K. A. Screening of crude extracts of six medicinal plants used in South-West Nigerian unorthodox medicine for antimethicillin resistant Staphylococcusaureus activity. B.M.C Complementary and Alternative Medecine, 2005; 5, pp. 1-6.

4. Institut Pasteur. Les maladies infectieuses: les staphylococcies, http://www.pasteur.fr/actu/presse/documentation/staphylo.html, 2007. Consulté le 06 Avril 2010.

5. Holmes A., Ganner M., McGuane S., Pitt T. L., Cookson B. D., Kearns A. M., S. aureus Isolates Carrying Panton-Valentine Genes in England and Wales: Frequency, Characterization, and Association with Clinical Disease. J. Clin. Microbiol. 2005; 43(5): 2384-2390.

6. Sevin Eric, Larmaraud-Sevin Odile, Legrand Patrick. Approche moléculaire de la résistance à la méticilline de Staphylococcus aureus. Revue Française des Laboratoires, 1999, 09(315): pp. 24-25.

7. Coulibaly K. Evaluation de l'activité antifongique des extraits d'écorces d'essences commerciales, de la catégorie P1 de la forêt classée de Mopri, Tiassalé (Sud de la Côte d'Ivoire). Mémoire D.E.A. d'Ecologie Tropicale, Option Végétale, 2006; Université de Cocody-Abidjan, U.F.R. Biosciences, Côte d'Ivoire, 62 p.

8. N'Guessan K. Contribution à l'étude ethnobotanique chez les Krobou de la Sous- préfecture d'Agboville (Côte-d'Ivoire). Thèse de Doctorat de 3e cycle, F.A.S.T., Laboratoire de Botanique, 1995; Univ. Nat. de Côted'Ivoire, $\mathrm{N}^{\circ} 217$ / 95, $557 \mathrm{p}$.

9. N’Guessan K. Plantes médicinales et pratiques médicales traditionnelles chez les peuples Abbey et Krobou du Département d'Agboville (Côte-d'Ivoire). Thèse de
Doctorat d'Etat ès Sciences Naturelles, 2008; U.F.R. Biosciences, Laboratoire de Botanique, Université de Cocody-Abidjan, Côte d'Ivoire, N 561 / 2008, 235 p.

10. Zirihi G. N. et Kra A. K. M. Evaluation de l'activité antifongique de Microglossa pyrifolia (Lam.) O. Ktze (Asteraceae) "PYMI" sur la croissance in vitro de Candida albicans. Revue médicale et pharmacopée Africaine, 2003, 17, pp. 11-18.

11. Zirihi G. N. Kra A. K. M. Etien D. T. Etude botanique et évaluation des activités antifongiques de Mitracarpus villosus (Rubiaceae) et Spermacoce verticillata (Rubiaceae) sur la croissance in vitro de Aspergillus fumigatus, Revue médicale et pharmacopée Africaine, 2007; 20, pp. 9-17.

12. CA-SFM, Edition de janvier 2009: Comite de l'Antibiogramme de la Société Française de Microbiologie. Recommandations, 2009. Association reconnue d’Utilité publique, Décret du 17 Mai 1993 (J. O. n 119) $49 \mathrm{p}$.

13. Dosso M. Faye Kette H. Documents Techniques Antibiotiques, Université National de Côte d'Ivoire, Faculté de Médecine, Département de Microbiologie, Laboratoire de Bactériologie-Virologie, Abidjan, 1995; $178 \mathrm{p}$.

14. Eloff J. N. A sensitive and quick microplat method to determine the minimal inhibitory concentration of plant extracts for bacteria. Planta Medica. 1998; 64(8): pp. 711-713.Al-Bayatt F. A. Al-Mola H. Antibacterial and antifungal activities of different parts of Tribulus terrestris L. growing in Iraq. Journal of Zhejiang University Sciences. 2008; 9 (2): pp. 154-159.

15. Kamanzi A. K. Plantes médicinales de Côte d'Ivoire : Investigations phytochimiques guidées par des essais biologiques. Doctorat d'Etat ès Sciences, Biologie Végétale, Université de Cocody, Abidjan, Côte d'Ivoire 2002, 176 p. Sanofi-Diagnostics-Pasteur, Abaques de lecture, Antibiogramme Pasteur. Technique des disques par diffusion en milieu gélosé pour les bactéries à Croissance rapide (18 à 24 h.). Détermination de la sensibilité aux agents antibactériens édition 1993.

16. Berche P., Gaillard J. L., Simonet M. Les bactéries des infections humaines. Flamarion, Médecine \& Sciences, 1991; 660 p.

17. Abayomi S. Plantes médicinales et médecine traditionnelle d'Afrique. A la recherche d'agents bio-actifs. Edition KARTHALA, 1996; pp. 191-219.

18. Pareck J. and Chanda S.V. In vitro antimicrobial activity and phytochemical analysis of some Indian medicinal plants, Turkish Journal of Biology, 2007; 31, pp. 53-58.

19. Bouhdid S. Idaomar M. Zhiri A. Baudoux D. Skali 
N.S. Abrini J. Thymus essential oils: Chemical composition and in vitro antioxydant and antibacterial activities. Congré international de Biochimie, 2006; Agadir.

20. Ali Shtayeh M. S. Yaghmour R. M. R. Faidi Y. R. Salem K. Al Nuri M. A. Antimicrobial activity of 20 plants used in folkloric medicine in the Palestinian area. Journal of Ethno Pharmacology, 1998; 60: pp. 265-271.

21. Adewunmi C. O. Agbedahunsi J. M. Adebajo A.

C. Aladesanmi A. J Murphy N. Screening of Nigerian medicinal plants for trypanocidal properties. Journal of Ethnopharmacology, 2001; 77, pp. 19-24.

22. Mbwambo H. Z. Moshi J. M. Masimba J. P. Kapingu C. M. and Nondo S. R. Antimicrobial activity and brine shrimp toxicity of extracts of Terminalia brownii roots and stem. BMC Complementary and Alternative Medicine, 2007; 7, pp. 1-5.

23. Coulibaly K., Zirihi Guede N., Amari A. S. G. Evaluation de l'activité anticandidosique des extraits hydro-alcooliques d'écorces de huit espèces ligneuses commerciales, de la forêt de Mopri, Tiassalé (Côte d'Ivoire). Ethnopharmacologia, 2010, n 46, pp. 81- 86. 24. Cowan M. M. Plant pruducts as antimicrobial agents. Clinic. Microbial. Rev., 1999; 12, pp. 564-582. 25. Taylor J. L. S. Rabe T. McGraw L. J. Jager A. K. Van Staden J. Towards the scientific validation of traditional plants. Plant Growth Regul. 2001; pp. 34: 23-37.

26. Cavin A. L. Contribution à la connaissance taxonomique et chimique de fruits africains du genre Detarium (Fabaceae-Caesalpiniaceae) : D .microcarpum Guill. et Perr. et des formes comestibles et toxiques de D. seneegalense J. F. Gmel. Thèse de doctorat. 2007; Genève, 277 p.

27. Stavrianakou S. Liakopoulos G. and Karabourniotis G. Boron deficiency effects on growth, photosynthesis and relative concentrations of phenolics of Dittrichia viscosa (Asteraceae). Environmental and Experimental Botany (Elsevier), 2005; pp. 293-300. 